\title{
Histological Comparison of the Edible Water Frog (Pelophylax ridibundus Pallas, 1771) Gonads Before and After Reproduction Period
}

\begin{abstract}
Ahmet Alkaya ${ }^{1, a, *}$, Hülya Şereflişan ${ }^{1, b}$
${ }^{I}$ Department of Aquaculture, Faculty of Marine Sciences and Technology, Iskenderun Technical University, 31200 Iskenderun, Turkey *Corresponding author

A R T I C L E I N F O A B S T R A C T

Research Article

In this study, testicular and ovarian structures of Pelophylax ridibundus (Pallas, 1771) were histologically examined before and after reproduction period in male and female individuals. Fortyeight $(24 \delta \hat{\jmath}, 24+9$ ) $)$ adult frogs were collected from Gölbaşı Lake in Hatay. The average weight and length values of female frogs were found to be $56.61 \pm 19.59 \mathrm{~g}$ and $79.54 \pm 7.07 \mathrm{~mm}$; while, the average weight and length values of male frogs were $36.63 \pm 12.84 \mathrm{~g}$ and $69.29 \pm 9.15 \mathrm{~mm}$, respectively. Frogs were brought to the frog farm established in Aydinc1k and placed in breeding ponds with a width of $1 \mathrm{~m}^{2}$. Frogs in the ponds were brought to the laboratory of Iskenderun Technical University in different periods, before breeding (March) and after breeding (June). Then, histological samples were taken from the ovary and testis. The female frogs were determined ready for reproduction. Moreover, a large number of mature oocytes in the before breeding ovaries in vitellogenic stage, while after reproduction oocytes in primary structure and oocytes which have atresia status observed. Also, an increase in the thickness of the theca layer was determined. In the male frog seminiferous tubules containing a large number of spermatogonia, spermatocyte, spermatid, and a small number of spermatozoons including sperm bundles and leydig cells were found before reproduction. After the reproduction, the density of spermatogonia, spermatocyte, and spermatids were decreased; while, the density of spermatozoon and sperm bundle were increased in the seminiferous tubules. This study will contribute to the determination of mating and spawning in frog breeding by revealing the histological status of the gonad structure of $P$. ridibundus in the breeding process.
\end{abstract}

\section{Introduction}

Examination of the histological status of the gonads in the reproduction period of economically important species provides an advantage in breeding studies. The changes occurring in the liver or gonads before and after the reproduction period and the differences caused by environmental effects can be followed by histological research (Gernhofer et al., 2001). Histological changes seen in the gonads have been considered as an important factor for understanding the life cycle of frogs and the developmental basis of reproductive cells (Erazo et al., 2016). In particular, it is of great importance to explain the levels of gonadal development and gonadal differentiation in economically important breeding frog species. Also, knowing the histophysiological structure of the species belonging to the Ranidae family, which is economically cultivated, makes an important contribution to the production rate (Arauco et al., 2007; Bambozzi et al., 2004).
There are few reports on the histology of testis and ovary of Rana cyanophlyctis, Rana hexadactyla, Bufo melanostictus (Saidapur, 1989), Rana curtipes (Gramapurohit, 2004), and Rana cyanophlyctis (Saidapur and Nadkarni, 1975; Pancharatna and Saidapur, 2009). Oocytes are classified into six stages based on their appearance, colors and size (Dumont, 1972). Following the formation of spermatogenesis in the Ichthyophis tricolor and Uraeotyphlus $c f$., firstly primary and secondary spermatogonia, primary and secondary spermatocytes, round and long spermatids, and lastly, sperm were detected in the testicles (Smita et al., 2004).

Intense histological changes in the gonads are observed during the reproduction period between spring and autumn. Reproduction in frogs continues from the first week of April until the end of May depending on the temperature change (Samantha and Stephen, 2013). While protein, fat, and glycogen reserves during the hibernation of the frogs 
are relatively enough for sustaining life, reproductive action must be carried out before the summer months to restore these essential nutrients for continuing levels in the reproduction process (Rugh, 1951). The seasonal gonad cycle of most amphibian species is evident and their breeding activities are highly sensitive to environmental changes. It is known that the hormones lead to, in amphibians, the production and growth of spermatic cells and ovarian follicles, environmental effects, and nutrition (Lofts 1974; Saidapur, 1989). P. ridibundus is one of the most common frog species in our country and it is exported to many countries in Europe in great amounts due to its economic value (Şereflişan and Alkaya, 2016). Moreover, any information regarding the reproduction of this species is important for our country.

The aim of study, indicate the histological changes in the gonads before and after frog reproduction period. Also, knowing the changes in the gonads during the reproduction period are thought to contribute significantly to the production in the frog breeding studies.

\section{Material and Method}

In this study, edible male and female frogs $(P$. ridibundus) which have economic importance was used.

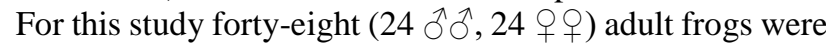
collected from Gölbaşı Lake in Hatay $\left(36^{\circ} 30^{\prime} 16.4^{\prime \prime} \mathrm{N}\right.$ 36 29'39.0"E) in March 2015. During the frog collected process temperature $19^{\circ} \mathrm{C}$ and humidity was $40 \%$ measured. Frogs were brought to the frog farm established in Aydincik (3608'39.2"N 33०19'19.4"E) and placed in breeding ponds with a width of $1 \mathrm{~m}^{2}$. Frogs in the ponds were brought to the laboratory of Iskenderun Technical University in different periods, before breeding (March) and after breeding (June). The average weight and length of female frogs collected from nature were found to be $56.61 \pm 19.59 \mathrm{~g}$ and $79.54 \pm 7.07 \mathrm{~mm}$; while, the average weight and length of male frogs were $36.63 \pm 12.84 \mathrm{~g}$ and $69.29 \pm 9.15 \mathrm{~mm}$, respectively. Gonadosomatic index (GSI) was calculated for each frog March and June. GSI was based on the weight ratio of each gonad to the body weight. The average GSI value of female March and June $7.35 \pm 1.53 ; 1.27 \pm 1.02$ that the average GSI value of male frogs March and June $0.29 \pm 0.04 ; 1.47 \pm 0.99$ respectively.

The female and male frogs were kept in ice-containing containers for 30 minutes and then treated with $25 \mathrm{ml}$ chloroform spilled cotton for the competition of anesthesia procedure in the laboratory. Then, the dissection procedure was carried out and removed gonads. The specimens were fixed in $10 \%$ formaldehyde. Samples were then dehydrated through a series of graded alcohols, cleared in xylene, infiltrated, and embedded into the paraffin. Gonad's paraffin wax blocks were cut into $4 \mu \mathrm{m}$ thick sections, stained with hematoxylin and eosin, and they were examined under Olympus CX 41 microscope (Akiyoshi and Inoue, 2012; Seixas Filho et al., 2013). Images were captured Olympus DP 20 digital camera. Pictures of gonads were taken from the most homogeneous fields possible.

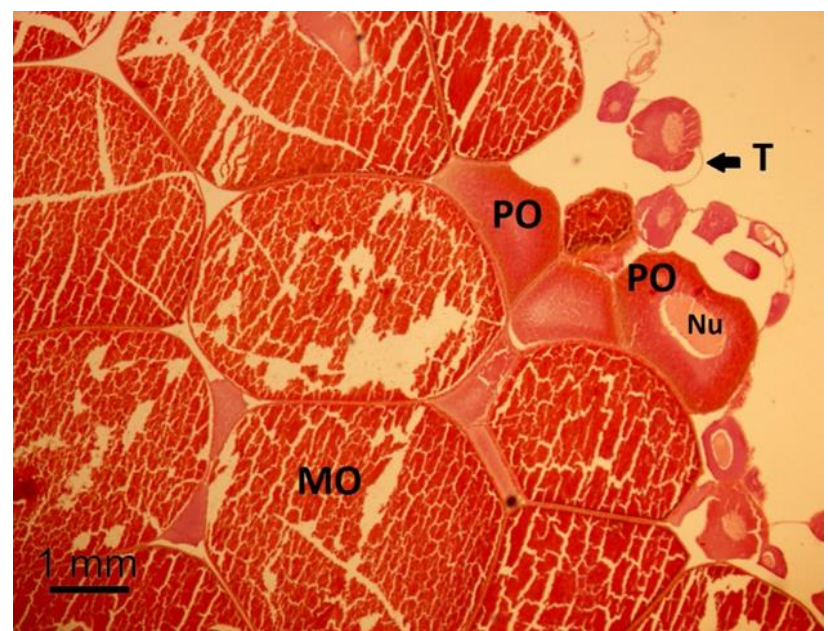

Figure 1. Female frog ovarium before breeding (MO: Mature Oocyte, PO: Primary Oocyte, Nu: Nucleus, T: Theca. H\&E)

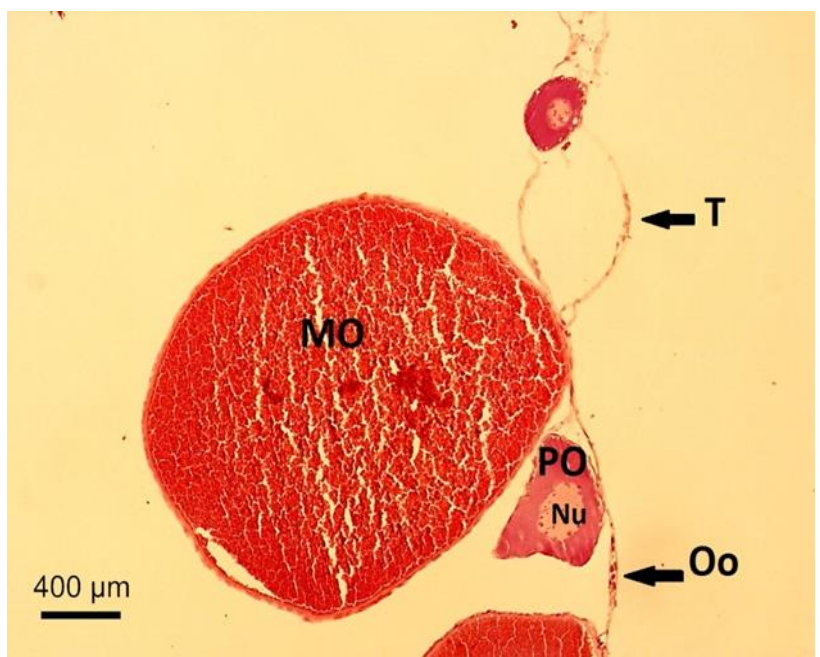

Figure 2. Female frog ovary, previtellogenic and vitellogenic oocytes in before breeding (MO: Mature Oocyte, Oo: Oogonia, PO: Primary Oocyte, Nu: Nucleus, T: Theca. H\&E)

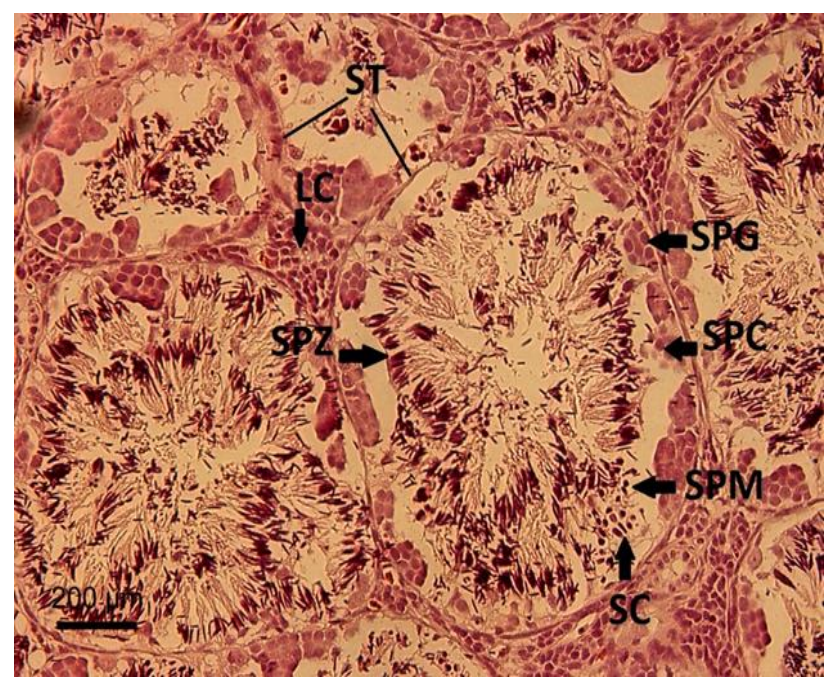

Figure 3. Male frog testis before breeding (LC: Leydig

Cell, SC: Sertoli Cell, ST: Seminifer tubule, SPG:

Spermatogonia, SPM: Spermatid, SPC: Spermatocyte, SPZ: Spermatozoon. H\&E) 


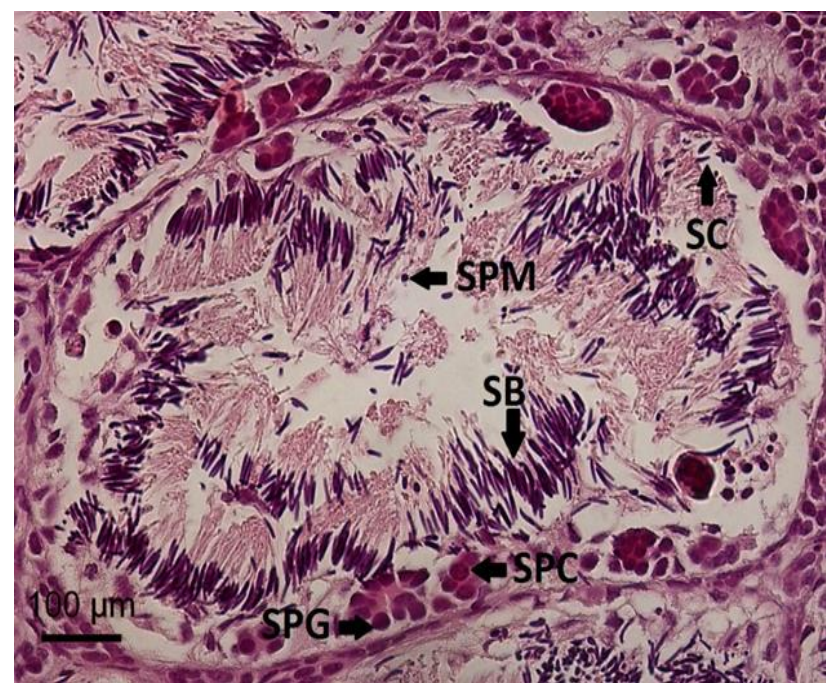

Figure 4. Male frog testis before breeding (SB: Sperm Bundle, SC: Sertoli Cell, SPG: Spermatogonia, SPM: Spermatid, SPC: Spermatocyte. H\&E)

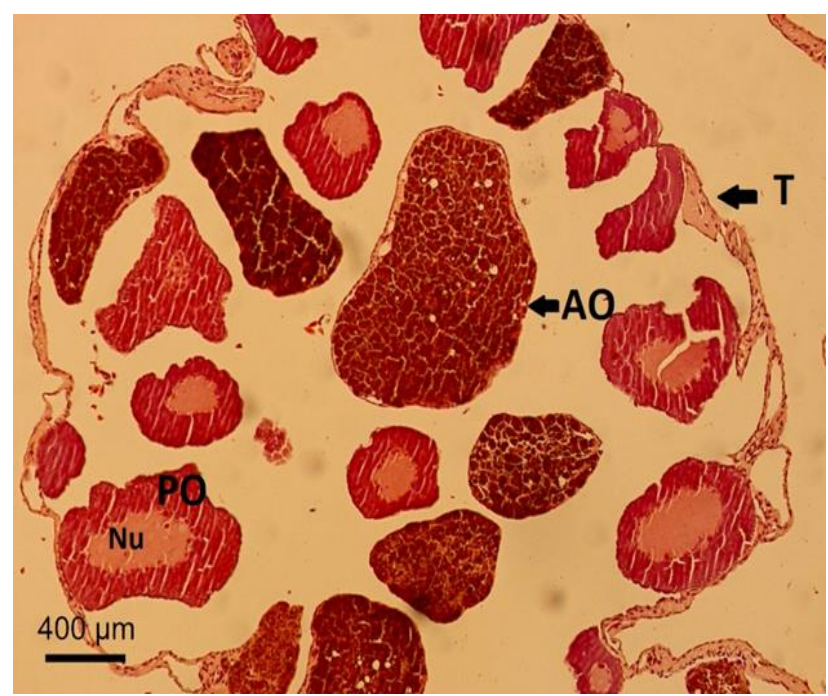

Figure 5. Female ovaries after breeding (AO: Atresia Oocyte, PO: Primary Oocyte, Nu: Nucleus, T: Theca. $\mathrm{H} \& \mathrm{E})$

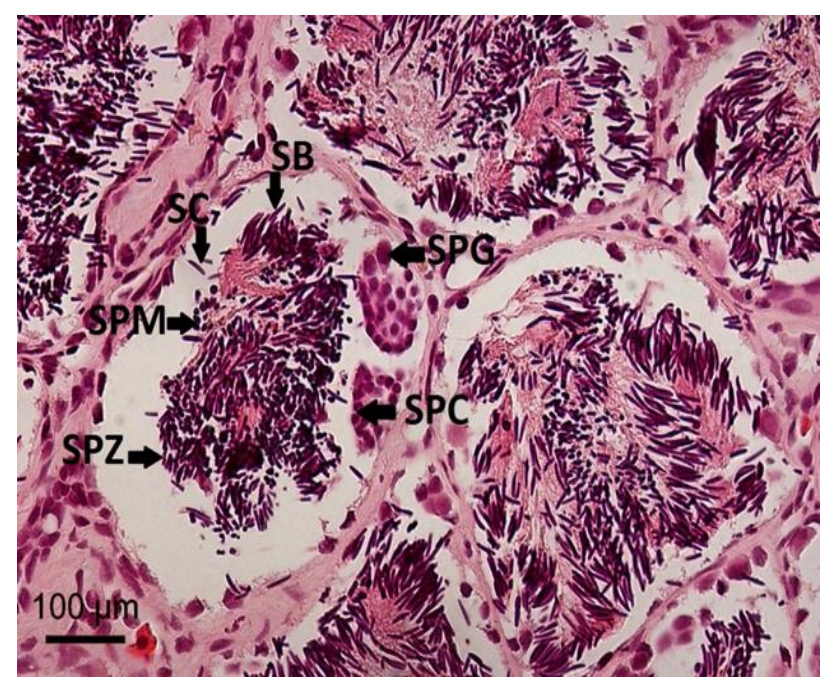

Figure 6. Male frog testis after reproduction (SB: Sperm

Bundle, SC: Sertoli cell, SPG: Spermatogonia, SPM:

Spermatid, SPC: Spermatocyte, SPZ: Spermatozoon. $\mathrm{H} \& \mathrm{E})$

\section{Results}

Histological Status of Frog Ovaries Before the Reproduction Period

When the samples of ovaries were taken before the reproduction period in female frogs, a large number of mature oocytes were detected in the ovaries in the vitellogenic stage. Therefore, it was determined that female frogs were ready for reproduction. In this period, it was observed that oocytes coexist in different stages of vitellogenic stage and primary structure belonging to the previtellogenic stage in ovaries (Figure 1). In addition, it was determined that oocyte production continues and the theca was found as a thin structure (Figure 2).

\section{Histological Status of Frog Testis Before the Reproduction Period}

When the testicles of male frogs collected from nature were examined at the beginning of the reproduction period (March); a large number of spermatogonia, spermatocyte, spermatid, and a small number of spermatozoons and sperm bundles were detected in the seminiferous tubules (Figure 3). In March, a large number of leydig cells were seen in the intertubular areas between the seminiferous tubules (Figure 4). Leydig cells are known to contribute to the continuation of reproduction by secreting testosterone hormone.

\section{Histological Status of Frog Ovaries After the Reproduction Period}

After spawning from the frogs in breeding ponds in April and May, the ovaries of female frogs were examined histologically. In June, the most common in the ovaries of female individuals were primary oocytes (Previtellogenic) and atresia oocytes (browning and degradation of oocytes) (Postvitellogenic). Also, the thickness of the theca was increased (Figure 5).

\section{Histological Status of Frog Testis After the} Reproduction Period

From the male frogs placed in breeding ponds, the histological status of the testicles was examined after reproduction (June). After the reproduction, it was found that the density of spermatogonia, spermatocyte, and spermatids were decreased in the seminiferous tubules of male frogs, but the density of spermatozoon and sperm bundle were increased (Figure 6).

\section{Discussion}

The development stages of the ovaries throughout the year and the eggs matured in six stages and that the mature oocytes were not observed in the November to February, but it was determined in the ovary samples taken from the March-October period (Sretarugsa et al., 2001). Annual reproductive cycle investigated with Fejervarya limnocharis that identified a large number of mature oocytes in female individuals in March, April, and May (reproduction period) (Othman et al., 2011). In this study, similarly with other studies, a large number of mature oocytes were detected before reproduction took place in the ovaries of female frogs grown in nature (March). Oogenesis was divided in two fundamental stages: 
previtellogenic and vitellogenic. Oogonias are the elements that form the nests germinative cells and are located in the periphery of the ovary (de Oliveira and de Souza Santos, 2004). Germinative cells in female frogs are classified into five types: oogonias, previtellogenic oocyte, vitellogenesis step oocyte, vitellogenic and postvitellogenic oocytes (Iturriaga et al., 2012). In this study, oocytes belonging to different stages of previtellogenic (primary structure oocytes) and vitellogenic stage (mature oocytes) were detected in the ovaries of female frogs that were collected from nature and brought to the frog farm before reproduction took place.

One of the studies with Rana leptoglossa detected oogonia, primary oocytes, and mature oocytes before the breeding period in the female ovaries. In addition, primary and mature oocytes were detected in the reproduction period in ovaries; on the other hand, only oogonial cells were detected after the reproductive period (Saha and Gupta, 2011). In this study, before reproduction takes place in the ovaries of female frogs grown in nature; oogonia, primary oocyte, and mature oocytes are detected; while, oogonia, primary oocytes, and atresia oocytes are detected after reproduction. The appearance of stage I and II or previtellogenic oocytes throughout the year as in other anurans ( Sklavounou and Loumbourdis,1990). Oocytes in the developmental stage I. and III. (Primer) are detected every term during the year in Rana tigrina ovaries (Hoque and Saidapur, 1994). Similarly, primary oocytes were observed in the ovaries of female frogs, which were collected from nature and brought to the frog farm, both before and after reproduction. On the other hand, these findings that there is always a reserved pool of oocytes.

It has been reported that after spawning in $R$. tigrina, oocytes were detected in the postvitellogenic atresia status (Hoque and Saidapur, 1994; Pancharatna and Saidapur, 1985). In another study, reported that the structure of some oocytes in the ovaries was disrupted and transformed into atresia oocytes during the reproduction period in amphibians (Masood-Parveez, 1987). Moreover, the melanocyte pigments in gonadal structures participated in gonadal regression observed after the maturation of germinative cells (Besseau and Faliex 1994; Grier and Taylor, 1998). That atresia oocytes may be seen in $R$. tigrina at any time of the year, but their number was increased with the decrease of mature oocytes in the VI stages after the most reproduction period (Sretarugsa et al., 2001). A study of female Pelophylax bedriagae, decreased the number of mature oocytes in the ovary after spawning (Akef, 2012). However, in this study after the reproduction period (June), mature oocytes were not observed in the ovaries of female frogs. Also, previtellogenic oocytes containing atresia status were increased, and the thickness of the theca was increased.

During a year, it has been reported that $R$. cyanophlyctis is observed in the atresia structure of follicles in its ovaries and their number is affected especially hormones (gonadotropins), by the stress of growing undernutrition and culture (Pancharatna and Saidapur 1992; Saidapur 1989). During the present study, it is thought that oocytes in the atresia structure seen in ovaries are had reproductive and hormonal origins (Hoque and Saidapur 1994; Sretarugsa et al., 2001). Reported that female frogs completed vitellogenesis in a summer study with Rana palustris (Resetarits and Aldridge, 1987). The number of mature oocytes in $P$. bedriagae's ovaries decreased after spawning period and that vitellogenesis was active throughout the year and was seen many times outside the reproductive and reproductive period (Akef, 2012). In this study, it can be said that developing oocytes can continue to vitellogenesis since it is known that female frogs with primary oocytes that have not completed their development in the ovaries after reproduction can produce eggs several times during the same reproduction period.

In the seminiferous tubules of male frogs both before reproduction (March) and after reproduction (June); spermatogonia, spermatocyte, spermatid, spermatozoon, and sperm bundle were detected. Similar spermatic structures were also identified as a result of the study conducted in Rana catesbeiana testicles (Sretarugsa et al., 2000). Moreover, seminiferous tubules of $P$. ridibundus has the structural pattern found in most anurans (Duellman and Trueb, 1994; Kardong, 2002). In comparison to $P$. ridibudus observed in the present study, in a study carried out by Kalt (1976) testes of male X. laevis and found 11 stages of germ cells. In a study carried out by Smita et al., (2004) spermatogenesis was completed after seven stages. Also, primary and secondary spermatogonia, primary and secondary spermatocytes, round and long spermatids, and lastly spermatozoon were observed in the testes following the formation of spermatogenesis in I. tricolor and $U$. narayani species. Examined the structural features of $E$. planirostris gonads histologically during spermatogenesis of germinal cells and divided spermatogenesis of germinal cells by six types: spermatogonia, spermatocyte I, spermatocyte II, early and late spermatids, and spermatozoon (Iturriaga et al., 2012).

Although in the seminiferous tubule's spermatozoon, spermatocyte and spermatids are observed, it contains mostly spermatogonia in January-February (before the reproduction period). Further, the development of gonad between March and June (reproduction period), secondary sexual characters and that most of the spermatogonia are transformed into spermatocytes. Which are detected secondary spermatogonia have been reported in the lumen of the testicular epithelium (Raucci and Di Fiore, 2007). In this study, it was found that the seminiferous tubules of male frogs collected from nature contain a large number of spermatogonia, spermatocyte, spermatid, and a small number of spermatozoon and sperm bundle before reproduction. It was determined that the number of spermatogonia, spermatocytes, and spermatids were decreased in the seminiferous tubules of male frogs, but the number of spermatozoon and sperm bundle were increased after the reproduction. Moreover, a study with Rana ridibunda that this situation was effective in the frog's continuous reproductive potential (Kaptan and Murathanoğlu, 2008).

Studies with $R$. ridibunda and $R$. leptoglossa, it has been reported that the number of spermatids increased in the testicles of male frogs during the reproduction period (April-June), and spermatids decreased after reproduction (Saha and Gupta, 2011; Sklavounou and Loumbourdis, 1990). However, in this study, it was found that the density of spermatids before reproduction was higher in the seminiferous tubules of male frogs collected compared to post-reproduction. Reported that male individuals 
increased their sperm count in March, April, and May (reproductive period) in their study with $F$. Limnocharis (Othman et al., 2011). In this study, it was determined that the density of spermatozoon and sperm bundle increased in June in the frogs. The reproductive cycle will be related to prevailing climatic conditions in habitats, and even slight annual changes in environmental conditions can disrupt reproductive cycles (Sretarugsa et al., 2000). Even in the same species, it has been stated that histological differences may occur in testicles and ovaries in the reproductive period (Rastogi et al., 1978). However, in this study, the present findings suggest that any histological differences between frogs result from climatic conditions were not detected.

\section{Conclusion}

As a result of histological observations in testicles and ovaries before and after reproduction; It has been determined that female and male individuals of this species ( $P$. ridibundus) have gonadial cells necessary for reproduction and ready for reproduction from March. Moreover, after the reproduction atresia oocytes were detected with the start of gonadial regression in females, while sperm germ cells decreased in males and sperm remained in bundles. Therefore, this study will contribute to the breeding process by revealing the histological status of the species gonads in the reproduction process of frogs.

\section{References}

Akef MSA. 2012. Female Reproductive Cycle in a Southern Population of the Water Frog (Pelophylax bedriagae) in Egypt. Russian Journal of Herpetology, 19: 251-260.

Akiyoshi H, Inoue AM. 2012. Comparative Histological Study of Hepatic

Architecture in the Three Orders Amphibian Liver. Comparative Hepatology, 11: 1-8. doi: http://dx.doi.org/10.1186/1476-592611-2

Arauco LRR, De Stéfani, MV, Nakaghi LSO, Oliveira-Bahia VRL. 2007. Histology of kidney, liver and intestine of bullfrog tadpoles (Rana catesbeiana) Fed with diets containing propolis. Ciência Rural, Santa Maria, 37: 1436-1441. doi: https://doi.org/10.1590/S0103-847820070005000 34

Bambozzi AC, Seixas-Filho JT, Thomaz LA, Oshiro LMY, Braga LGT, Lima SL. 2004.

Efeito do fotoperíodo sobre o desenvolvimento de girinos de rãtouro (Rana catesbeiana Shaw, 1802). Revista Brasileira de Zootecnia, 1: 1-7. doi: https://doi.org/10.1590/S151635982004000100001

Besseau L, Faliex E. 1994 Resorption of unemitted gametes in Lithognathus mormyrus (Sparidae, Teleostei): a possible synergic action of somatic and immune cells. Cell Tissue Res., 276: 123-132. doi: 10.1007/BF00354791

De Oliveira C, de Souza Santos LR. 2004. Histological characterization of cellular types during Scinax fusiovarios oogenesis (Lutz) (Anura, Hylidae). Revista Brasileira de Zoologia, 21: 919-923. doi: https://doi.org/10.1590/S010181752004000400029 Dumont JN. 1972. Oogenesis in Xenopus laevis (Daudin). 1. Stages of oocytes development in laboratory-maintained animals. J. Morph., 136: 153- 79. doi: 10.1002/jmor. 1051360203

Duellman WE, Trueb L. 1994. Biology of Amphibians. 2nd Edition. Baltimore. The Johns Hopkins University Press. ISBN 978-0801847806

Erazo PMA, Goldberg J, Jerez A. 2016. Gonadal development in the Neotropical high Andean frog Dendropsophus labialis (Amphibia: Hylidae). Cuad. herpetol., 30: 57-68. doi:10.31017/9055
Gernhofer M, Pawet M, Schramm M, Müller E, Triebskorn R. 2001. Ultrastructural Biomarkers as Tools to Characterize the Health Status of Fish in Contaminated Streams. Journal of Aquatic Ecosystem Stress and Recovery, 8: 241-226. doi: http://dx.doi.org/10.1023/: 1012958804442

Gramapurohit NP, Shanbhag BA, Saidapur SK. 2004. Growth, sexual maturation and body size dimorphism in the Indian bullfrog, Hoplobatrachus tigerinus. Herpetologica, 60: 414419. doi: 10.1655/03-97

Grier HJ, Taylor RG. 1998. Testicular maturation and regression in the common snook. Journal of Fish Biology, 53: 521-542. DOİ: http://dx.doi.org/10.1111/j.1095-8649.1998. tb00999.x.

Hoque B, Saidapur SK. 1994. Dynamics of oogenesis in the tropical anuran Rana tigrine (Amphibia: Ranidae) with special reference to vitellogenic cycles in wild-caught and captive frogs. J. Biosci., 19: 339 - 352. doi: http://dx.doi.org/10.1007/BF02716824

Iturriaga M, Rodríguez Y, Sanz A. 2012. Structural and ultrastructural description of the gonads of Eleutherodactylus planirostris (Anura: Eleutherodactylidae). Herpetology Notes, 5: 281-290.

Kalt MR. 1976. Morphology and kinetics of spermatogenesis in Xenopus laevis. J Exp Zool 195: 393-408. doi:10.1002/jez. 1401950306

Kaptan E, Murathanoglu O. 2008. Annual Morphological Cycles of Testis and Thumb Pad of the Male Frog (Rana ridibunda). The Anatomical Record, 291:1106-1114. doi: 10.1002/ar. 20723

Kardong KV. 2002. Vertebrates: Comparative Anatomy, Function, Evolution. 3rd Edition. Boston, McGraw-Hill. ISBN 978-0072909562

Lofts B. 1974. Reproduction. In B Lofts, ed. Physiology of the Amphibia. Vol. 2. New York: Academic Press, pp. 107-200. ISBN: 978-0323140034

Masood-Parveez U. 1987. Some aspects of reproduction in the female apodan amphibian Ichthyophis. Ph.d. Thesis. Dharwad, India: Karnatak University.

Othman MS, Khonsue W, Kitana J, Thirakupt K, Robson MG, Kitana N. 2011. Reproductive mode of Fejervarya limnocharis (Anura: Ranidae) caught from Mae Sot, Thailand based on its gonadosomatic indices. Asian Herpetological Research 2: 41-45. doi: 10.3724/SP.J.1245.2011.00041

Panchratna K, Saidapur SK. 1985. Ovarian cycle in the frog, Rana cyanophlyctis A quantitative study of follicular kinetics in relation to body mass, oviduct, and fat bodies cycle. J. Morphol., 186: 135-147. doi: 10.1002/jmor.1051860202

Pancharatna K, Saidapur SK. 1992. A study of ovarian follicular kinetics, oviduct, fat body, and liver mass cycles in laboratory-maintained Rana cyanophlyctis in comparison with wild-caught frogs. J. Morphol., 214: 123-129.

Pancharatna M, Saidapur SK. 2009. Ovarian cycle in the frog Rana cyanophlyctis: A quantitative study of follicular kinetics in relation to body mass, oviduct, and fat body cycles. J. Morphol., 1862: 135-147. doi: 10.1002/jmor.1052140202

Rastogi RK, Lela L, Delrio G, Meglio MD, Russo A, Chieffi G. 1978. Environmental influence on testicular activity in the green frog, Rana esculenta. J. Exp. Zool., 206: 49-64.

Raucci F, Fiore MM. 2007. The c-kit receptor protein in the testis of green frog Rana esculenta: seasonal changes in relationship to testosterone titres and spermatogonial proliferation. Reprod., 133: 51-60. doi: 10.1530/rep.1.01009

Resetarits WJ, Aldridge RD. 1988. Reproductive biology of a cave-associated population of the frog Rana palustris. Can. J. Zool., 66: 329-333.

Rugh R. 1951. The Frog Its Reproduction and Development. The Blakiston Company, Toronto. ISBN: 978-0733426094

Saha BK, Gupta BBP. 2011. Studies on Annual Activity Cycle of Gonads and Breeding Behavior of the Endangered Frog, Rana leptoglossa (Cope, 1868). I.J.S.N., 2: 683-691.

Samantha PK, Stephen CL. 2013. Changes in breeding phenology of eastern Ontario frogs over four decades. Ecol Evol., 3: 835-845. doi: 10.1002/ece3.501 
Saidapur SK, Nadkarni VB. 1975. Seasonal variation in the structure and function of testis and thumb pad in the frog Rana tigrina (Daud.). Indian J. Exp. BioI., 13: 432-438.

Saidapur SK. 1989. Reproductive cycles of Indian amphibians; in Reproductive cycles of Indian vertebrates (ed.) S K Saidapur (New Delhi: Allied Press). pp. 166-224. ISBN 8170232554

Sklavounou PK, Loumbourdis NS.1990. Annual Ovarian Cycle in the Frog, Rana ridibunda, in Northern Greece. Journal of Herpetology, 24:185. doi: 10.2307/1564226

Smita M, Oommen OV, Jancy MG, Akbarsha MA. 2004. Stages in spermatogenesis of two species of caecilians, Ichthyophis tricolor and Uraeotyphlus cf. narayani (Amphibia: Gymnophiona): Light and electron microscopic study. Journal of Morphology, 261: 92-104. doi: 10.1002/jmor.10231
Seixas Filho JT, Hipólito M, Pereira MM, Martins AMCRPF, Rodrigues E, Mello SCRP. 2013. Liver histopathological changes in breeding bullfrogs. Acta Scientiarium, Animal Science, 35:461-465. doi: https://doi.org/10.1590/S180692902017000400001

Sretarugsaa P, Chavadeja J, Jerareungrattanab A, Sobhona P. 2000. Structure a Development of the Testis of Bullfrog, Rana catesbeiana, and Their Changes during Seasonal Variation. Science Asia, 26: 69-80.

Sretarugsaa P, Weerachatyanukula W, Chavadeja J, Kruatrachueb M, Sobhona P. 2001. Classification of Developing Oocytes, Ovarian Development and Seasonal Variation in Rana tigerina. Science Asia, 27: 1-14.

Şereflisan H, Alkaya A. 2016. The biology, economy, hunting and legislation of edible Frogs (Ranidae) Intended for Export in Turkey. Turkish Journal of Agriculture - Food Science and Technology, 4: 600-604, 2016. doi: https://doi.org/10.24925/ turjaf.v4i7.600-604.654 